\title{
Potential impact of host pest fed on Bt-modified corn on the development of Chrysoperla carnea (Stephens) (Neuroptera: Chrysopidae)
}

\author{
Saad Moussa ${ }^{1 *}$, Fatina Baiomy ${ }^{1}$, Karim Abouzaid ${ }^{1}$, Mona Nasr ${ }^{1}$, Essam M. Moussa ${ }^{1}$ and Essam A. Kamel ${ }^{2}$
}

\begin{abstract}
Laboratory experiments were conducted to study the potential impact of genetically modified corn hybrid, transgenic Bacillus thuringiensis (Bt)-expressing (Cry2Ab/1 Ac), and the corresponding isogenic untransformed Bt-free hybrid on biological parameters of the green lacewing predator, Chrysoperla carnea (Stephens). The effectiveness of transgenic (Bt)-expressing (Cry2Ab/1Ac) on C. carnea developmental parameters (larval duration, pupal duration, mortality \%, pupation \%, adult emergence \%, and adult duration time) was investigated in the first experiment. In the second experiment, the effect of Bt Cry2Ab and Cry1 Ac partially purified toxins on the hatchability of C. carnea eggs compared to cypermethrin was examined. Additionally, the toxicity effect of Angoumois grain moth, Sitotroga cerealella, eggs sprayed with BtCry2Ab/1Ac mixture and cypermethrin on C. carnea was tested. The results showed that the mortality percentage of $C$. carnea fed on aphids reared on Bt corn (40\%) was less than that fed on aphids reared on non-Bt corn (50\%). Moreover, the larval mortality \%, net pupation, and adults' emergence percentage of $C$. carnea larvae fed on aphids reared on Bt corn and non-Bt corn were not significantly different. On the other hand, the hatchability data showed that the chemical insecticide (cypermethrin) severely affected the C. carnea eggs compared to Cry2Ab/1Ac toxins. These findings proved that adopting biopesticide formulation based on Bt toxins or Bt-modified crops will not only affect $C$. carnea but also enhance its ability as a potential biological pest control agent.
\end{abstract}

Keywords: Bt toxins, Bt- modified corn, Chrysoperla carnea, Bioassay experiments, Sitotroga cerealella, Development, Cypermethrin, Aphid

\section{Background}

Different Bacillus thuringiensis (Bt) have been used widely to control lepidopterans, dipterans, and coleopterans insect pests over the last five decades. Among the environmentally friendly pesticides, $B$. thuringiensis-based products alone account for $90-92 \%$ of the $1 \%$ market share of biopesticides in the total pesticide market. Generally, B. thuringiensis endotoxins are considered as safe biopesticides to vertebrates and beneficial arthropods and are often highly toxic to insect pests. Genes encoding Bt

\footnotetext{
* Correspondence: saadmousa@insectbiotech.sci.eg; saadmousa@yahoo.com 'Insect Biotechnology and Molecular Biology Unit, Plant Protection Research Institute (PPRI), Agricultural Research Center, 7 Nadi El-Seid Street, Dokki, Giza 62156, Egypt

Full list of author information is available at the end of the article
}

toxins were among the first to be used in genetic engineering of plants to overcome insect resistance.

Since 1996, plants have been modified with short sequences of genes from $B t$ to express the crystal protein. In this technology, plants themselves can produce the proteins and protect themselves from insect damage. The use of genetic engineering techniques to transfer desired traits in insect, disease, and weed control has provided farmers with new tools to control some stubborn problems (James, 2004). Some of the first genetically engineered crops have been modified to express insecticidal crystalline (Cry) proteins derived from the common soil bacterium B. thuringiensis (Bt) Berliner (Perlak et al., 1991). These so-called Bt crops are protected from the feeding of various groups of insect pests. They provide pest control solutions that are highly 
effective and yet very specific, leading to substantial direct benefits for farmers as well as providing greater flexibility in crop management practices. Among them, Bt corn is considered as an ideal crop system for comparing possible non-target effects of transgenic (Bt) and conventional insecticide control. This crop is heavily treated with insecticides for lepidopteran pests and has a shorter crop cycle than other transgenic crops. Thus, there is a great chance of ecological disruption, at least from insecticides, and less time for non-target populations to recover from these disturbances before the end of the crop cycle (Rose and Dively, 2007). Like any insect control technology, transgenic plant may present a risk to the natural enemy community, due to indirect contact with Cry protein by feeding on intoxicated organisms, or changes in plant chemical. On the contrary, reductions in insecticide use resulting from planting Bt corn should be beneficial to natural enemies (Betz et al., 2000). Endotoxins from Bt produced in transgenic Bt crops are generally not toxic to predatory and parasitic arthropods (Schoenly et al., 2003).

Green corn leaf aphid (GCLA), Rhopalosiphum maidis (Fitch), is a major pest of corn in Egypt, Middle East, and elsewhere; heavy infestations cause yield loss by more than 35\% (Al-Eryan and El-Tabbakh, 2004). It is also considered as a major pest of sorghum, barley, sugar cane, millet, wheat, and banana in various parts of the world. This pest is attacked by various predators of different families, viz., Chrysopidae, Syrphidae, and Coccinellidae. Green lacewing, Crysoperla carnea (Stephens) (Chrysopidae), is the most effective biological control agent of aphid species. The larva of $C$. carnea has relatively a wide range of prey acceptance (Preetha et al., 2009), which includes aphids, whiteflies, eggs of moths, and other soft-bodied insects. As a result of the polyphagous ability and voracious nature of $C$. carnea in addition to its vast geographical distribution (New, 1975), there is easiness of mass multiplication (Araujo and Bichao, 1990) and tolerance to several pesticides (Hassan et al., 1985). C. carnea has received numerous attentions from farmers as well as researchers as a potential biological pest control agent. The effectiveness of C. carnea as a biological control agent has been demonstrated in field and greenhouses and reported to give about 100\% lepidoptran pest control when used along with Trichogramma spp. (Hagley and Miles, 1987; Rincon, 1999). Therefore, the current study aims to investigate the potential impact of $B t$ transgenic plants on green lacewing predator, $C$. carnea.

\section{Materials and methods}

\section{Rearing of Sitotroga cerealella (Olivier)}

The eggs of Angoumois grain moth, S. cerealella (Olivier), were used as a natural food source for mass production of the green lacewing, C. carnea. In order to maintain S. cerealella pest under laboratory condition, its mother colony was kindly provided by the Stored Grain Department at the Plant Protection Research Institute. To obtain a mass production of $S$. cerealella eggs, the insect culture was maintained according to the method described by Hassan (1995) with some modifications where a bulk of soft wheat grains were brought to the laboratory and were sterilized at $120{ }^{\circ} \mathrm{C}$ for $2 \mathrm{~h}$. About $2-3 \mathrm{~kg}$ of sterilized wheat grains was poured into sterilized and clean metal trays $(70 \times$ $50 \mathrm{~cm}$ size). These trays were kept horizontally on the bench and infested with $1 \mathrm{~g}$ of $S$. cerealella eggs $/ \mathrm{kg}$ of wheat grains in each tray and immediately transferred into large cages for 10-12 days. The trays were then taken and kept vertically in ovipositor cages for 25-30 days till adult emergency and egg production. The deposited S. cerealella eggs were collected in small jars in 2-day intervals and were sieved in order to remove all the insect scales.

\section{Rearing of predator, C. carnea}

The starter culture of the green lacewing, C. carnea, was established by collecting the adult stage from cotton field, insecticide-free and transferred immediately to the laboratory. This culture was maintained under lab condition for several generations before starting the experiments. The adults of $C$. carnea were taken from original culture and were mated in plastic boxes. A number of ten pairs of adults were placed in plastic boxes $(22 \times$ $13 \times 10 \mathrm{~cm}$ ) and were covered with black muslin cloth for egg laying. A semi-artificial diet solution was prepared according to Morrison (1985). The adults were provided with droplets of mixed yeast and sugar on muslin cloth. The deposited eggs were collected daily and kept in glass jars until hatching. The hatched larvae were reared on S. cerealella eggs as mentioned above.

\section{Rearing of the aphid, Rhopalosiphum maidis (Fitch)}

In order to obtain enough culture of aphid that fed for several generations on Bt corn plants, a number of 20 30 individuals of $R$. maidis were released on Bt corn which contained a synthetic Cry2Ab/1Ac gene encoding a nearly full length Cry2Ab protein. Both transgenic and non-transgenic corn plants were sown and grown in the greenhouses. Three months after cultivation, the nymphs of GCLA were collected from the infested corn leaves for predator feeding assay.

\section{Predator feeding assay}

A. Feeding effect of aphid reared on Bt transgenic lines on the development of $C$. carnea

In order to study the influence of feeding C. carnea on hosts that fed on transgenic line, the infested leaves with $R$. maidis individuals of $\mathrm{Bt}$ corn and non-Bt corn greenhouses were collected and transferred to the lab for 
predator assay. Twenty individuals of the second instar larvae of $C$. carnea were kept individually in culture tubes; each tube was considered as one replicate. Fifty aphids were collected from the infested corn leaves then introduced to each larva daily till pupation. Daily observations were performed till adult stage. In each assay, the larval duration of the C. carnea, larval mortality percentage, pupation percentage, pupal duration, percentage of the emerged adult, percentage of assayed larvae survived till adult emergence and the number of aphid individuals eaten by each larva were recorded.

Also, to study the effect of Cry2Ab and Cry1Ac toxins on either egg hatchability or larval feeding of C. carnea, we undertook the following experiments:

\section{B. Bacillus thuringiensis Cry1Ac and Cry2Ab toxin preparation}

BtCry1Ac toxin was cultured and partially purified as described earlier by Abdullah et al. (2009). Additionally, protein concentration was determined by Bio-Rad protein assay based on the Bradford method using bovine serum albumin (BSA) as a standard (Bradford, 1976). The BtCry2Ab protoxin was partially purified according to methods described by Moussa et al. (2016). BtCry2Ab was inoculated in a 5-ml Loria broth (LB) culture tube and incubated overnight at $150 \mathrm{rpm}$ shaking at $37{ }^{\circ} \mathrm{C}$. The bacterial cell was sub-cultured in a bigger flask of LB media and kept to grow under the previous condition for 3-4 days. The cells were pelleted down using $5200 \mathrm{rpm}$ centrifugation at $4{ }^{\circ} \mathrm{C}$ for $10 \mathrm{~min}$. The pellet was re-suspended in lysis buffer (50 mM Tris; pH 8.0; $50 \mathrm{mM}$ EDTA; $15 \%$ sucrose; $10 \mu \mathrm{g} / \mathrm{ml}$ of lysozyme).

C. BtCry1Ac and Cry2Ab effects on egg hatchability of C. carnea

To study the effect of Bt Cry1Ac and Cry2Ab toxins on egg hatchability of C. carnea, 20 eggs of C. carnea were sprayed with different concentrations of the abovementioned toxins and left for hatching. Three replicates were used per each dose. In both toxins, three different concentrations were used viz. 4.0, 8.0, and $10.0 \mu \mathrm{g} / \mathrm{ml}$ in comparison to the recommended dose of chemical insecticide cyper-methrine $(2 \mu \mathrm{g} / \mu \mathrm{l})$ which was used as a positive control treatment. The negative control treatment sprayed with distilled water $\left(\mathrm{dH}_{2} \mathrm{O}\right)$ was also considered. The sprayed eggs were incubated at $27 \pm 1{ }^{\circ} \mathrm{C}$ for hatching and the eggs were daily observed till day fifth. The hatchability percentage of C. carnea was calculated and recorded.

D. Feeding effect of S. cerealella eggs sprayed with BtCry1Ac/2Ab toxins on C. carnea
To determine the feeding effect of $S$. cerealella eggs treated with Bt Cry1Ac and Cry2Ab toxins on green lacewing predator compared to the effect feeding of GCLA reared on Bt corn, the partially purified BtCry1Ac and BtCry2Ab toxins were sprayed on eggs of S. cerealella pest at various concentrations which ranged from 4 to $10 \mu \mathrm{g}$ toxin $/ \mathrm{ml} \mathrm{dH}_{2} \mathrm{O}$. Similarly, the negative and positive control treatments were also deliberated, but $\mathrm{Bt}$ toxins in this experiment were replaced with $\mathrm{dH}_{2} \mathrm{O}$ (as a negative control) and cypermethrin compound (as a positive control). In each concentration, three replicates of 20 green lacewings on the first day of the second larval instar were released on the treated eggs with a fine brush and then kept at the abovementioned laboratory condition for 4 days and examined 4 days after treatment. The experiments were repeated several times in order to obtain accurate data. The experiments were accomplished at $26 \pm 1{ }^{\circ} \mathrm{C}$ and $65-70 \% \mathrm{RH}$.

\section{Data analysis}

One-way analysis of variance (ANOVA) was applied by the Duncan multiple range test for comparison of means at $P<0.05$, Student's $t$ test, and depletion rates, which were computerized according to IBM-SPSS, 2011). Additionally, Abbott's formula (Abbott, 1925) was implemented to correct the larval mortality percentage.

\section{Results and discussion \\ Development of $C$. carnea fed on aphids reared on Bt corn}

The developmental parameters including larval and pupal duration of $C$. carnea fed on aphids reared on $\mathrm{Bt}$ corn and non-Bt corn are shown in Table 1. The obtained data showed that each larva of $C$. carnea fed on aphid reared on Bt lines consumed fewer individuals than those reared on aphids fed on non-Bt lines. The rate of each larval predator consumption of aphid

Table 1 Effect of aphids fed on $B t$ and non-Bt corn on the development of the immature stages of, C. carnea

\begin{tabular}{lll}
\hline Parameter (s) & Bt corn line & Non-Bt corn line \\
\hline $\begin{array}{l}\text { Mean number of aphids consumed } \\
\text { by each larva }\end{array}$ & $222.5 \pm 7.28$ & $253.5 \pm 6.65^{*}$ \\
Larval duration (mean/day) & $9.0 \pm 0.11$ & $9.9 \pm 0.17^{*}$ \\
Pupal duration (mean/day) & $10.4 \pm 0.07$ & $10 \pm 0.08^{*}$ \\
Mortality \% & $40 \%$ & $50 \%$ \\
Pupation (completed) \% & $60 \%$ & $50 \%$ \\
$\begin{array}{l}\text { Adult emergence \% } \\
\begin{array}{l}\text { Percentage of assayed larvae survived } \\
\text { till adult emergence }\end{array}\end{array}$ & $60 \%$ & 100 \\
\hline
\end{tabular}

Data represented as mean \pm SE

"Significant at $P<0.01$ using Student's $t$ test 
individuals reared on Bt corn (222.5 individuals) was less than that reared on non-Bt corn (253.5 individuals) and the difference between the two mean numbers was significant. Moreover, the larval duration was affected significantly when predator larvae fed on aphid reared on non-Bt corn plants (9.0 days) was compared to larvae fed on aphid reared on Bt corn (9.9 days). The pupal duration on Bt corn was significantly longer than that on non-Bt corn and the percentages of pupation were 60 and $50 \%$ respectively. Inversely, the larvae of C. carnea completed their larval development and pupal period in a shorter time (19.4 days) compared to those on non-Bt corn (19.9 days). On the other hand, the mortality percentage of $C$. carnea fed on aphids reared on Bt corn (40\%) was lesser than that fed on aphids reared on non-Bt corn (50\%). Results indicated no detrimental effects of Bt plants on the biological activity of C. carnea. Romeis et al. (2004) pointed that the observed negative effects on $C$. carnea larvae provided with Cry2Ab fed on lepidopteran larvae were due to a reduction in prey quality and not to a direct toxic effect. Also, this observation is in agreement with the finding of Schnepf et al. (1998 and De Maagd et al. ( 2001). They reported that no specific binding sites for Cry2Ab were detectable on the midgut brush border membrane vesicles isolated from $C$. carnea larvae since the specific binding site of the protein on midgut receptor is a prerequisite for the completion of Bt toxicity. Generally, data analysis cleared that the larval mortality, pupation percentage, and adult's emergence percentage of $C$. carnea larvae fed on aphids reared on Bt corn were not affected significantly as compared to the non-Bt corn line. Dutton et al. (2002) showed that C. carnea fed on two preys (Rhopalosiphum padi and Tertranychus urticae) which were reared on Bt corn did not affect survival and predator development. Moreover, Head et al. (2001) proved that the residues of Bt protein were not found in the aphid bodies when fed on Bt transgenic corn or on artificial diets containing the same Bt protein, while Tian et al. (2013) confirmed that there were no differences in any of the fitness parameters (larval survival, development time, fecundity, and egg hatchability) regardless if C. rufilabris consumed cabbage looper, Trichoplusia ni, or fall army worm, Spodoptera frugiperda, that had consumed Bt or non-Bt plants.

\section{Comparison between the effect of Cry1 Ac and Cry2Ab toxins on egg hatchability of $C$. carnea}

The effect of Cry1Ac and Cry2Ab on egg hatchability of C. carnea compared to the chemical pesticide (Cypermetherin) as a positive control and $\mathrm{dH}_{2} \mathrm{O}$ as a negative control treatment is illustrated in Table 2. Although we tested high doses of both toxins (4.0, 8.0, and $10.0 \mu \mathrm{g}$ toxin $/ \mathrm{ml}$ ), the data indicated that there were no significant differences between Cry1Ac and Cry2Ab concentrations on egg hatchability. Also, there was no significant difference between the abovementioned concentrations and the negative control except $\mathrm{Cry} 2 \mathrm{Ab}$ at $4.0 \mu \mathrm{g}$ where the mean number of hatched eggs that treated with Cry $2 \mathrm{Ab}$ at $4.0 \mu \mathrm{g}$ produced 19.33 eggs and that treated with $\mathrm{dH}_{2} \mathrm{O}$ (negative control) produced 16.66 eggs with significant difference between two applications.

On the other hand, the hatchability of $C$. carnea eggs treated with cypermetherin (positive control) was nil and the difference between the positive control and all other treatments was significant. Tian et al. (2013) confirmed that Cry1Ac and Cry2Ab did not affect the egg hatchability of C. rufilabris.

\section{Effect of Bt toxins on C. carnea}

Data in Table 3 indicated that the two concentrations (4 and $8 \mu \mathrm{g} / \mathrm{ml}$ ) of both BtCry1Ac and Cry2Ab mixture caused larval mortality of 2.5 and $5.0 \%$ respectively, while mortality percentage was $10.83 \%$ when larvae were fed on S. cerealella eggs sprayed with cypermethrin. On the other hand, there was no larval mortality recorded in negative control $\left(\mathrm{dH}_{2} \mathrm{O}\right)$. These results are in accordance with Rodrigo-Simon et al. (2006) who found that there was no negative effect of Cry2Ab, Cry1Ac, or $\mathrm{Cry} 1 \mathrm{Ab}$ on lacewing larvae of Cry1Ac binding sites in the mid-gut epithelium.

Additionally, Dutton et al. (2002) and Obrist et al. (2006) did not find any direct effect for Cry1A protein class on lacewing larvae. Considering that the green lacewing is a generalist predator which, in addition to feeding on lepidopteran larvae and mites, also feeds on aphids and other insect eggs in the field, it is highly unlikely that Bt crops pose any risk to this beneficial predator.

Table 2 Effect of Bt Cry1Ac and Cry2Ab toxins on egg hatchability of C. carnea

\begin{tabular}{|c|c|c|c|c|c|c|c|c|}
\hline Treatments & Cry1Ac ( $\mu \mathrm{g} /$ & & & Cry $1 \mathrm{Ab}(\mu \mathrm{g} /$ & & & Cypermetherin & $\mathrm{dH}_{2} \mathrm{O}$ \\
\hline Concentrations & 4.0 & 8.0 & 10.0 & 4.0 & 8.0 & 10.0 & (+ve control) & (-ve control) \\
\hline $\begin{array}{l}\text { Mean no. of hatched } \\
\text { C. carnea eggs }\end{array}$ & $19.0 \pm 1.13^{\mathrm{a}}$ & $18.33 \pm 1.13^{\mathrm{a}}$ & $18.0 \pm 1.13^{\mathrm{a}}$ & $19.33 \pm 1.13^{\mathrm{a}}$ & $18.33 \pm 1.13^{\mathrm{a}}$ & $17.33 \pm 1.13^{\mathrm{a}}$ & $0.0^{\mathrm{b}}$ & $16.66 \pm 1.13^{\mathrm{a}}$ \\
\hline
\end{tabular}

Data represented as mean $\pm \mathrm{SE}$

${ }^{a}$, Insignificant difference between similar litter using Duncan multiple range test at $P<0.05$ 
Table 3 Effect of $S$. cerealella eggs sprayed with cypermethrin and the mixture of Cry1 Ac and Cry 2Ab on the larval mortality of C. carnea

\begin{tabular}{llll}
\hline Treatments & Concentrations & $\begin{array}{l}\text { Mean no. of } \\
\text { mortality }\end{array}$ & $\begin{array}{l}\text { \% Corrected } \\
\text { mortality }\end{array}$ \\
\hline Cry1Ac+Cry 2Ab & $4 \mu \mathrm{g} / \mathrm{ml}$ & $0.5^{\mathrm{a}}$ & 2.50 \\
& $8 \mu \mathrm{g} / \mathrm{ml}$ & $1.0^{\mathrm{a}}$ & 5.00 \\
Cypermethrin & $2 \mathrm{mg} / \mathrm{ml}$ & $2.2^{\mathrm{b}}$ & 10.83 \\
\hline
\end{tabular}

A number of twenty sprayed eggs of $S$. cerealella pest were kept in each replicate. Three replicates were used/ each concentration. The mixture of $\mathrm{Bt}$ Cry $1 \mathrm{Ac}$ and Cry $2 \mathrm{Ab}$ was compared to cypermethrin (positive control) and $\mathrm{dH}_{2} \mathrm{O}$ (negative control)

${ }^{a}, b$ Insignificant difference between similar letter using Fischer Exact Probability test at $P<0.05$

\section{Conclusions}

The overall conclusion of the current study is that Bt corn lines has no direct or indirect effect on C. carnea. A respectable number of developed and developing countries adopted transgenic crops two decades ago. But, several concerns still stand as obstacles to accept this technology by public. Effect of modified crops on the biological activity of the predation level of insect predators such as $C$. carnea is assumed to be a major problem. Therefore, the current study proved that the biological activity of $C$. carnea will not be affected by adopting Bt corn. This finding may also help the Egyptian Government to reconsider the adoption of Bt-modified crops plan for reclamation of 4 million feddan of the desert land in the coming years.

\section{Acknowledgements}

The authors thank the Plant Protection Research Institute and the Agriculture Research Center for facilitating the work during the study. We are gratefully acknowledged the Science and Technology Development Fund (STDF) for funding this work through the project number 4653. Also, we would like to thank the board of STDF organization for their support and encourages throughout the research.

\section{Authors' contributions}

SM has planed the outline of the research work, did the bioassay experiments and drafted the manuscript. FB carried out the data analysis and helped in cultivating the $\mathrm{Bt}$ corn. KA was responsible for rearing the $\mathrm{C}$ carnea predator and S. cerealella cultures. MN anticipated in collection the aphids individuals and preparing Bt toxins. EM carried out insect assay and data observations. EAK anticipated in insect collection and Bt toxin purification along with revising the draft of the manuscript. All authors read and approved the final manuscript

\section{Competing interests}

The authors declare that they have no competing interests.

\section{Publisher's Note}

Springer Nature remains neutral with regard to jurisdictional claims in published maps and institutional affiliations.

\section{Author details}

${ }^{1}$ Insect Biotechnology and Molecular Biology Unit, Plant Protection Research Institute (PPRI), Agricultural Research Center, 7 Nadi El-Seid Street, Dokki, Giza 62156, Egypt. ${ }^{2}$ Toxicology Unit, Animal Health Research Institute, Dokki, Egypt.
Received: 18 June 2017 Accepted: 6 December 2017

Published online: 15 March 2018

\section{References}

Abbott WS (1925) A method of computing the effectiveness of an insecticide. J Econ Entomol 18:265-267

Abdullah MAF, Moussa S, Taylor MD, Adange MJ (2009) Manduca sexta (Lepidoptera: Sphingidae) cadherin fragments function as synergists for Cry $1 \mathrm{~A}$ and $\mathrm{Cry} 1 \mathrm{C}$ bacillus thuringiensis toxins against noctuid moths Helicoverpa zea, Agrotis ipsilon and Spodoptera exigua. Pest Manag Sci 65(10):1097-1103

Al-Eryan MAS, El-Tabbakh SS (2004) Forecasting yield of corn, Zea mays infested with corn leaf aphid, Rhopalosiphum maidis. J Appl Entomol 128:312-315

Araujo J, Bichao MH (1990) Biotechnologia de producao de Chrysoperla carnea (Stephens) (Neuroptera: Chrysopidae). Boletin de Sanidad Vegetal, Plagas 16:113-118

Betz FS, Hammond BG, Fuchs RL (2000) Safety and advantages of bacillus thuringiensis-protected plants to control insect pests. Regul Toxicol Pharmacol 32:156-173

Bradford M (1976) A rapid and sensitive method for the quantitative of microgram quantities utilizing the principle of protein-dye binding. Anal Biochem 72:248-254

De Maagd RA, Bravo A, Crickmore N (2001) How bacillus thuringiensis has evolved specific toxins to colonize the insect world. Trends Genet 17:193-199

Dutton A, Klein H, Romeis J, Bigler F (2002) Uptake of Bt toxin by herbivores feeding on transgenic maize and consequences for the predator Chrysoperla Carnea. Ecol Entomol 27:441-447

Hagley EAC, Miles N (1987) Release of Chrysoperla Carnea Stephens (Neuroptera, Chrysopidae) for control of Tetranychus urticae Koch (Acarina: Tetranychidae) on peach grown in a protected environment structure. Can Entomol 119:205-206

Hassan, S.A. 1995. Improved method for the production of the Angoumois grain moth, Sitotroga cerealella (Oliv.). Trichogramma and other egg parasitoids, Cairo, Egypt, October 4-7, 1994, Paris, 157-160

Hassan SA, Klinghauf F, Shanin F (1985) Role of Chrysopa carnea as an aphid predator on sugar beet and the effect of pesticides. Z Angew Entomol 100:163-174

Head G, Brown CR, Groth ME, Duan JJ (2001) Cry2Ab protein levels in phytophagous insects feeding on transgenic corn: implications for secondary exposure risk assessment. Entomologia Experimentalis et Applicata 99:37-45

IBM-SPSS 20 .2011. IBM SPSS, Statistical Package for Social Science. Standard Version, Copyright SPSS Inc., 1989-2011, All Rights Reserved, IBM license, Copyright ${ }^{\oplus}$ IBM and SPSS Inc., 2011, New York

James C. 2004. Global Status of Commercialized Biotech/GM Crops. 2004, 1995, 1996, http://www.isaaa.org/resources/publications/briefs/default.asp. Brief 43, 2011.

Morrison, R. K. 1985. Chrysopa carnea, pp. 419-425. In: P. Singh and R.F. Moore (eds.), Handbook of insect rearing, 2nd ed. Elsevier, Amsterdam.

Moussa S, Kamel E, Ismail MI, Mohammed A (2016) Inheritance of bacillus thuringiensis Cry1C resistance in Egyptian cotton leafworm; Spodoptera littoralis (Lepidoptera: Noctuidae). Entomol Res 46(1):61-69

New TR (1975) The biology of Chrysopidae and Hemerobiidae (Neuroptera) with reference to their use as biological agents: a review. Transaction of the Royal Entomological Society of London 127:115-140

Obrist LB, Dutton A, Romeis J, Bigler F (2006) Biological activity of Cry1Ab toxin expressed by Bt maize following ingestion by herbivorous arthropods and exposure of the predator Chrysoperla carnea. BioControl 51:31-48

Perlak FJ, Fuchs RL, Dean DA, McPherson SL, Fischhoff DA (1991) Modification of the coding sequence enhances plant expression of insect control protein genes. Proc Natl Acad Sci U S A 88:3324-3328

Preetha G, Stanley J, Manoharan T, Chandrasekaran S, Kuttalam S (2009) Toxicity of imidacloprid and diafenthiuron to Chrysoperla carnea (Stephens) (Neuroptera: Chrysopidae) in the laboratory conditions. J Plant Prot Res 49(3):290-296

Rincon V (1999) Trichogramma technical bulletin. I.N.C., P.O. box, 95, OAK view, CA. 93002 (805), pp 643-5407

Rodrigo-Simon A, de Maagd RA, Avilla C, Bakker PL, Molthoff J, González-Zamora JE, Ferré J (2006) Lack of detrimental effects of bacillus thuringiensis cry toxins on the insect predator Chrysoperla carnea: a toxicological, histopathological, and biochemical analysis. Appl Environ Microbiol 72:1595-1603 
Romeis J, Dutton A, Bigler F (2004) Bacillus thuringiensis toxin (Cry1 Ab) has no direct effect on larvae of the green lacewing Chrysoperla carnea (Stephens) (Neuroptera: Chrysopidae). J Insect Physiol 50:175-183

Rose R, Dively GP (2007) Effects of Bt transgenic and conventional insecticide control on the non-target natural enemy community in sweet corn on the abundance and diversity of arthropods. Environ Entomol 36:1254-1268

Schnepf E, Crickmore N, Van Rie J, Lereclus D, Baum J, Feitelson J, Zeigler DR, Dean DH (1998) Bacillus thuringiensis and its pesticidal crystal proteins. Microbiol Mol Biol Rev 62:775-806

Schoenly KG, Cohen MB, Barrion AT, Zhang W, Gaolach B, Viajante VD (2003) Effects of bacillus thuringiensis on non-target herbivore and natural enemy assemblages in tropical irrigated rice. Environ Biosaf Res 2:181-206

Tian JC, Wang XP, Long LP, Romeis J, Naranjo SE (2013) Bt crops producing Cry1AC, CryzAb and Cry $1 \mathrm{~F}$ do not harm the green lacewing, Chrysoperla rufilabris. PLoS One 8(3):e60125. https://doi.org/10.1371/journal. Pone.0060125

\section{Submit your manuscript to a SpringerOpen ${ }^{\circ}$ journal and benefit from:}

- Convenient online submission

- Rigorous peer review

- Open access: articles freely available online

- High visibility within the field

- Retaining the copyright to your article

Submit your next manuscript at $\boldsymbol{s p r i n g e r o p e n . c o m ~}$ 